\title{
An Overview of Image-Guided Percutaneous Microwave Ablation of Renal Cell Carcinoma
}

\author{
Renal Hücreli Karsinomda Görüntüleme Eşliğinde Perkütan Mikrodalga Ablasyon: \\ Genel Bakış
}

\author{
Berat Acu', Mehmet Ali Kaptan', Çiğdem Öztunalı² \\ ${ }^{1}$ Eskişehir Osmangazi University Faculty of Medicine, Department of Radiology, Eskişehir, Turkiye \\ ${ }^{2}$ Gazi University Faculty of Medicine, Department of Radiology, Ankara, Turkiye
}

\begin{abstract}
Renal cell carcinoma (RCC) accounts for approximately 3\% of malignancies and $80-90 \%$ of malignant neoplasms of the kidney in adults. The incidence of RCC continues to increase. Due to widespread use of cross-sectional imaging modalities, small and localized tumors are now being detected at an early stage. Percutaneous image-guided thermal ablation for early stage RCC is a minimally invasive technique that has rapidly gained acceptance as an alternative to surgery. This technique provides a low incidence of complications, shorter operative-time, protection of renal function, lack of inherent surgery risks, and shorter hospital stay while remaining an effective method of adequate destruction of tumor tissue. The current ablation techniques include cryoablation, radiofrequency ablation (RFA), high-intensity focused ultrasound and microwave ablation (MWA). Image-guided percutaneous MWA has been effectively and safely applied to treat renal tumors in select patients. In contrast to RFA, percutaneous MWA has the advantage of providing higher temperatures in a shorter time. Thus, MWA allows a more uniform tumor necrosis than RFA. The indications for renal MWA include T1a or T1b tumors ( $\leq 4 \mathrm{~cm}$ or $4-7 \mathrm{~cm})$, patients with multiple comorbidities who are poor candidates for resection, a tumor in a solitary kidney, bilateral renal tumors, hereditary renal tumors, renal insufficiency, von Hippel-Lindau syndrome, and palliative treatment of hematuria. In conclusion, percutaneous MWA appears to be a safe and effective treatment option for T1a and T1b tumors and for patients who are poor surgical candidates.
\end{abstract}

Keywords: Microwave ablation, Percutaneous, Renal cell carcinoma

\section{Öz}

Renal hücreli karsinom (RHK) yetişkin malignitelerinin yaklaşık \%3'ünü, renal malignitelerin ise \%80-90'ını oluşturmaktadır. RHK insidansı artmaya devam etmektedir. Kesitsel görüntüleme yöntemlerinin yaygın kullanımı ile küçük ve lokalize tümörler günümüzde erken dönemde saptanabilmektedir. Görüntüleme eşliğinde perkütan termal ablasyon, erken evre RHK'nin tedavisinde cerrahi tedaviye bir alternatif olarak kabul görmüştür. Bu teknik düşük komplikasyon riski, azalmış operasyon zamanı, renal fonksiyonların korunması, cerrahiye bağlı risklerin önüne geçmesi ve kısa hastanede kalış süresi gibi avantajlar sağlamaktadır. Termoablasyon teknikleri kriyoablasyon, radyofrekans ablasyon (RFA), yüksek intensiteli odaklı ultrason, mikrodalga ablasyon (MWA) gibi yöntemleri içerir. Görüntüleme eşliğinde perkütan MWA seçilmiş hastalarda renal tümörlerin tedavisinde güvenli ve etkili bir yöntem olarak uygulanabilir. RFA'ya kıyasla MWA ile daha kısa sürelerde daha yüksek sıcaklık değerlerine ulaşılabilir. Böylelikle MWA, RFA'ya kıyasla daha üniform bir tümör nekrozu sağlar. Renal MWA endikasyonları; T1a ve T1b tümörler ( $\leq 4 \mathrm{~cm}$ or $4-7 \mathrm{~cm}$ ), komorbid hastalığı olan cerrahi rezeksiyon için uygun olmayan hastalar, soliter böbrekte tümör, bilateral renal tümörler, kalıtsal renal tümörler, renal yetmezlik, von Hippel Lindau hastalığı ve hematüri palyasyonunu içerir. Sonuç olarak, perkütan MWA T1a ve T1b tümörlerin tedavisinde ve cerrahi tedavinin uygun olmadığı hastalarda güvenli ve etkili bir tedavi yöntemidir.

Anahtar Kelimeler: Mikrodalga ablasyon, Perkütan, Renal hücreli karsinom

Correspondence: Berat ACU MD, Eskişehir Osmangazi University Faculty of Medicine, Department of Radiology, Eskişehir, Turkiye

Phone: +90 2222392979 E-mail: beratacu@gmail.com ORCID-ID: orcid.org/0000-0001-9590-1052

Received: 14.08.2016 Accepted: 12.12.2017

Cite this article as: Acu B, Kaptan MA, Öztunalı Ç. An Overview of Image-Guided Percutaneous Microwave Ablation of Renal Cell Carcinoma. J Urol Surg 2018;5(1):1-3.

${ }^{\oplus}$ Copyright 2018 by the Association of Urological Surgery / Journal of Urological Surgery published by Galenos Publishing House. 


\section{Introduction}

Renal cell carcinoma (RCC) accounts for approximately $3 \%$ of all malignancies and $80-90 \%$ of malignant kidney neoplasms in adults (1). The incidence of RCC continues to increase. With the increasing use of cross-sectional imaging, small and localized tumors are being detected earlier. Radical nephrectomy had long been the only curative treatment for early stage RCC. Later, nephron-sparing surgery or partial nephrectomy has gained popularity and it has been used in the treatment of selected patients. Although a partial nephrectomy is less invasive than radical nephrectomy, it is technically more challenging and the incidence of serious complications remains high (2).

Percutaneous image-guided thermal ablation for early stage RCC is a minimally invasive technique that has rapidly gained acceptance as an alternative to surgery. This technique provides a low incidence of complications, shorter operative time, protection of renal function, lack of inherent surgery risks, and shorter hospital stay while remaining an effective method of adequate destruction of tumor tissue (2). Currently, thermal ablation of RCC is an alternative treatment option for patients who are poor candidates for surgery, such as the elderly patients, patients with comorbidities and patients with a prior history of surgery for RCC (3).

The current ablation techniques include cryoablation, radiofrequency ablation (RFA), high-intensity focused ultrasound and microwave ablation (MWA). Image-guided percutaneous MWA has been effectively and safely used to treat renal tumors in selected patients (1).

In contrast to RFA, percutaneous MWA has the advantage of providing higher temperatures in a shorter time. Thus, MWA allows a more uniform tumor necrosis than RFA. Also, MWA is less affected by the heat sink problem that occurs when the tumors are located in close proximity to large vessels (4).

The ablative treatment of tumors larger than $3-4 \mathrm{~cm}$ can be challenging due to incomplete ablation. In such cases, ablation of larger tumor volumes may be achieved with MWA. Regarding the follow-up of RCC patients treated with MWA treatment, a recent study has shown promising results with outcomes up to 3 years and a technical effectiveness rate of 98\% (5).

The indications for renal MWA include T1a or T1b tumors $(\leq 4$ $\mathrm{cm}$ or 4-7 cm), presence of multiple comorbidities, tumor in a solitary kidney, bilateral tumors, hereditary renal tumors, renal insufficiency, von Hippel-Lindau syndrome, and palliative treatment of hematuria.

The contraindications for RFA include an uncorrectable coagulopathy, infection/sepsis, poor life expectancy and extensive metastatic disease $(3,6)$.

\section{Patient Preparation and Ablation Procedures}

Before the treatment, all patients are evaluated with contrastenhanced computed tomography (CT) and ultrasound, and an optimal access route is determined on ultrasound. After administration of $1 \%$ lidocaine for local anesthesia, an ultrasound-guided biopsy is performed by an automatic biopsy gun with an 18-gauge cutting needle. If the tumor is located in close proximity to important structures, a spinal needle is situated between the tumor and adjacent structures and, a small volume of 5\% dextrose in sterile water is injected into the potential space between the tumor and the surrounding structures (hydrodissection). Since renal tumors are mostly located in close proximity to the bowel, ureter or pancreas; hydrodissection is more important in renal ablations than in hepatic ablations. For a safe ablation, more than $50 \%$ of procedures require hydrodissection. An ureteral stent placement or pyeloperfusion may be beneficial when the tumor is located adjacent to the ureter.

Using ultrasound guidance, microwave (MW) antenna is then inserted into the tumor. To achieve a larger ablation volume, two antennae can be used simultaneously in ablation of the tumors $\geq 2 \mathrm{~cm}$. For anesthesia, propofol and ketamine are generally administered in combination, intravenously. Generally, a power output of $50 \mathrm{~W}$ for 500 seconds is used during MWA. MW emission may be prolonged if the generated water vapor does not entirely include the tumor and the temperature does not reach $60^{\circ} \mathrm{C}$ or remain above $54^{\circ} \mathrm{C}$ for a minimum of 3 minutes. To prevent tumor seeding, the needle track is coagulated during the withdrawal of the antenna.

\section{Postprocedural Observation and Imaging Follow-up}

After MWA procedure, patients are closely monitored for possible side effects and complications, such as fever, pain, pleural effusion, hematuria, urinoma and skin burns. A urinalysis is performed, and serum urea nitrogen and creatinine are tested periodically after treatment (2). A contrast-enhanced CT is performed immediately after the ablation to evaluate technical success of the ablation and to assess possible complications. Follow-up imaging with contrast-enhanced CT or magnetic resonance imaging at $3,6,12,18$, and 24 months after ablation and yearly thereafter is recommended (3).

The management of RCC has notably changed in the last decade. Currently, a more conservative treatment for localized renal tumors is favored. Of these treatment alternatives, image-guided thermal ablation is the least invasive approach that avoids the mortality and morbidity of surgery in selected patients. Of the percutaneous thermal ablation techniques, RFA is more commonly used. For small RCCs, short-term and intermediate-term results of RFA is reported to be comparable to those of surgical resection (2). 
MW energy enables cell death by agitation of water molecules with the resultant frictional heat. For this purpose, a probe that generates an oscillating electromagnetic field of 900- to 2.450$\mathrm{MHz}$ frequency range is inserted into the tumor with image guidance. Within an induced electromagnetic field, dipolar water molecules try to align with the field. As the field starts to oscillate, water molecules try to get back into alignment and create frictional kinetic energy. This kinetic energy is then transformed to heat causing coagulative necrosis and subsequent cell death (7).

MWA offers some advantages over RFA. MWA has a larger zone of active heating than RFA and its transmission in tissues is not limited by desiccation and charring. The higher intratumoral temperatures that can be achieved with MWA allow ablation of larger tumor volumes in shorter durations. MWA is less affected by the heat sink effect and this feature may be useful in ablation of well-perfused tumors. Also, MWA allows the use of multiple antennae simultaneously in ablation of large-sized tumors (2).

Disadvantages of MWA include the risk of thermal injury to surrounding structures. Currently, the clinical data are less robust for MWA than for RFA (6).

In a prospective randomized trial of 102 RCC patients, MWA treatment (laparoscopic or percutaneous) was compared to partial nephrectomy (open or laparoscopic). Blood loss, complications and postoperative renal function decline were significantly better in MWA group than in the partial nephrectomy group. In this study, 3-year recurrence-free survival was not statistically significantly different (90.4\% for MWA group and $96.6 \%$ for partial nephrectomy group) (8). As for today, there is no other study comparing MWA and other modalities, including nephrectomy, RFA, cryoablation in the treatment of RCC (9).

After MWA procedure, follow-up imaging with contrastenhanced CT or MR at 3, 6, 12, 18, and 24 months after ablation and yearly thereafter is recommended (3). Biopsy can be used to confirm a suspected residual tumor in equivocal cases. Small foci of residual or recurrent tumor can be retreated with MWA (10).

\section{Conclusion}

Ablative treatments are increasingly being used for the treatment of early stage renal tumors. Currently, American Urological Association guidelines suggest the use of ablative treatments in patients with significant comorbidities who are poor surgical candidates and in patients with a solitary kidney who are at high risk for total loss of renal function after nephron-sparing surgery (4). Percutaneous MWA appears to be a safe and effective treatment option for T1a and T1b RCC. More experience with this technique should be gained before its widespread application (2).

\section{Ethics}

Peer-review: Internally peer-reviewed.

\section{Authorship Contributions}

Surgical and Medical Practices: B.A., M.A.K., Concept: B.A., M.A.K., Design: B.A., Data Collection or Processing: M.A.K., Ç.Ö., Analysis or Interpretation: B.A., M.A.K., Literature Search: B.A., Ç.Ö., Writing: B.A., Ç.Ö., M.A.K.

Conflict of Interest: No conflict of interest was declared by the authors.

Financial Disclosure: The authors declared that this study received no financial support.

\section{References}

1. Chen $C N$, Liang $P, Y u J, Y u X L$, Cheng ZG, Han ZY, Liu FY, Li X. Contrastenhanced ultrasound-guided percutaneous microwave ablation of renal cell carcinoma that is inconspicuous on conventional ultrasound. International Journal of Hyperthermia 2016.

2. Liang $P$, Wang $Y, Z$ Zhang $D, Y u X, G a o Y, N i X$. Ultrasound guided percutaneous microwave ablation for small renal cancer: initial experience. J Urol 2008;180:844-848.

3. Wells $S A$, Wheeler KM, Mithqal A, Patel MS, Brace CL, Schenkman NS. Percutaneous microwave ablation of T1a and T1b renal cell carcinoma: short-term efficacy and complications with emphasis on tumor complexity and single session treatment. Abdom Radiology (NY) 2016;41:1203-1211.

4. Khiatani V, Dixon RG. Renal ablation update. Semin Intervent Radiol 2014;31:157-166.

5. Hinshaw JL, Lubner MG, Ziemlewicz TJ, Lee FT, Jr, Brace CL. Percutaneous tumor ablation tools: microwave, radiofrequency, or cryoablation--what should you use and why? Radiographics 2014;34:1344-1362.

6. Clark T, Sabharwal T. Interventional radiology techniques in ablation: Springer Science \&t Business Media; 2012.

7. Simon CJ, Dupuy DE, Mayo-Smith WW. Microwave ablation: principles and applications. Radiographics 2005;25(Suppl 1)69-83.

8. Guan W, Bai J, Liu J, Wang S, Zhuang Q, Ye Z, Hu Z. Microwave ablation versus partial nephrectomy for small renal tumors: intermediate-term results. J Surg Oncol 2012;106:316-321.

9. Liang $\mathrm{P}, \mathrm{Yu} X-\mathrm{I}, \mathrm{Yu}$ J. Microwave ablation treatment of solid tumors: Springer; 2014.

10. Uppot RN, Silverman SG, Zagoria RJ, Tuncali K, Childs DD, Gervais DA. Imaging-guided percutaneous ablation of renal cell carcinoma: a primer of how we do it. AJR Am J Roentgenol 2009;192:1558-1570. 